\title{
Changes of Reef Community near Ku Lao Cham Islands (South China Sea) after Sangshen Typhoon
}

\author{
Yuri Ya. Latypovi,2, Nikolai Selin ${ }^{1}$ \\ ${ }^{1}$ A. V. Zhirmunsky Institute of Marine Biology, Far East Branch of Russian Academy of Sciences (FEB RAS), Vladivostok, Russia \\ ${ }^{2}$ Far Eastern State Natural Marine Biosphere Reserve, Vladivostok, Russia \\ Email: ltpv@mail.ru, nikselin@yandex.ru
}

Received February 15, 2012; revised March 7, 2012; accepted March 16, 2012

\begin{abstract}
Coral reefs of Ku Lao Cham Islands in the Central Vietnam were studied over a quarter of a century. It was established that the reefs of these Islands were lost after the Sangshen typhoon and a heavy flood, which happened in 2006. As a result of these natural phenomena a significant part of coral populations was physically destroyed, and a powerful export of clay substances from the nearest Vietnamese coast and from the Bung River, flowing into the sea opposite the Islands, causing abundant sedimentation and death of almost all the remaining scleractinian corals. At present, where formerly there were coral reefs, now there is algal-alcyonarian stage of succession of reef communities. This is typical, as a rule, for restoration of reefs after a destructive typhoon effect.
\end{abstract}

Keywords: Sangshen Typhoon; Reef Community; Change; Succession

\section{Introduction}

Bays along the coast and islands of the Central Vietnam are usually open and sandy, subject to the effect of wind. Their underwater slopes are formed by rubble-lump breakdowns mostly of granite rocks, turning with depth into stony deposits and further into sandy-silty platforms. A big Bung River, bringing daily thousands of tons of fresh and highly silted water, flows into the sea opposite the Ku Lao Cham Islands [1]. This continental outflow can be especially great in the periods of heavy floods and typhoons. Such peculiarity of coastal geomorphology and hydrology of this region has an effect on formation of its sparse reefs, which were thoroughly investigated for the first time by a joint Soviet-Vietnamese expeditions in 1984, 1987, and later by the WWF in 1992-1993 [2,3]. Species composition of corals (more than 200 species), population density of common species of macrobenthos (from 7 - 10 up to $200 \mathrm{ind} / \mathrm{m}^{2}$ ), and degree of substrate cover by corals $(75 \%-100 \%)$, formation of continuous settlements Acropora cytherea $20 \%$ - 45\% of substrate cover were investigated. Communities revealed on the basis of these data displayed is possible to examine completely satisfactory condition (optimal temperature and high transparency of the water, the lack of its eutrophication), as well as similarity of these reefs with those of the North and South Vietnam.

In October of 200610 provinces of Central Vietnam went through a powerful Sangshen typhoon. According to data provided by the meteorological center wind velocity exceeded $133 \mathrm{~km} / \mathrm{h}$ and sometimes reached $160 \mathrm{~km} / \mathrm{h}$. Heavy pouring rains, caused by the natural disaster, resulted in a fast rise of water level in local rivers. In many areas precipitation level reached $200-230 \mathrm{~mm}$. Erosion of rice fields, coastal and beach areas caused the loss of $80 \%$ of mangrove bushes and 95\% of coral reefs (based on an unpublished UNU-IAS Seminar Report). As is known, torrents of storm sewage are characterized by great desalination and turbidity due suspended matter, which is harmful for coral communities and results in their partial or at times complete mortality $[4,5]$.

When studying the same reefs at the same locations in 2010, considerable changes in composition and structure of reef communities were found. The community composition changes in this region are of interest for comparative studies with previous data, thereby increasing spatial validity of changes described for reefs of central and southern Vietnam but may be relevant for some areas of tne Pacific in which there were similar typhoons.

\section{Materials and methods}

Using SCUBA, we investigated the composition, distribution of scleractinian corals and mass species of macrobenthos, structure of communities in reef zones at seven (four studied earlier and two new control ones) sections in sandy and stony inlets and near rocky coasts (Figure 1). Investigations were carried out in accordance with the standard hydrobiological technique using quadrats and transects [6,7]. Abundance of mass species of 




Figure 1. Location of transects at Ku Lao Cham Islands. 1-6 -location of transects.

mollusks and echinoderms, branched, massive, encrusted and funnel-shaped scleractinian colonies, as well as the degree of substrate cover by corals were estimated along a $100 \mathrm{~m}$ transect frame divided into 100 squares with the area of $10 \mathrm{~cm}^{2}$ each. Photographing of reef landscapes, and their flora and fauna was conducted. More than 500 photos by Olympus and Canon digital cameras were made for later analysis of species composition $[8,9]$ and structure of community of coral reef survey methods $[10,11]$.

\section{Results and Discussion}

In 1987 the species diversity on various reefs ranged from 483 to 590 species, among them scleractinians composed 219 species. More than 20 species prevailed: macrophytes Padina australis, Caulerpa racemosa, Halophyllia ovalis, alcyonarians Sinularia dura and Sarcophyton trochelioforum, scleractinian Acropora cytherea A. robusta, A. humilis, A. digitifera, Montipora aequituberculata, M. hispida, Porites lobata, P. rus, Goniopora stokesi, Pavona decussata, Platygyra daedalia, Diploastrea heliopora, Galaxea fascicularis and Lithophyllum undulatum, mollusks Tridacna maxima, Ovula ovum and Cyprea arabica, echinoderms Diadema setosum, Holothuria atra, Linckia laevigata and Ophyocoma nigra. Only one alcyonarian species ( $S$. dura) formed monospecific settlements of colonies on significant areas in various reef zones, and two scleractinian species- $A$. cytherea and $P$. lichen - formed patches of mono-colonies in the reef-flat zone. Formation of several communities could be clearly traced [2].

The Algal-coral community was formed from the lower level of the intertidal zone to a depth of $2-2.5 \mathrm{~m}$. It was characterized by predominant development of algae, subordinate role of scleractinia, and permanent presence of mollusks and echinoderms. Living corals were represented by separate massive and crustacean colonies of Porites, Goniastrea, Favia, Favites, Galaxea, Hydnophora and single branched Pocillopora, Acropora, Seriatopora. The degree of substrate cover by corals rarely exceeded $10 \%$ - 15\%. Gastropods of the genera Trochus, Cypraea, Lambis, echinoderms Holothuria atra, H. hilla, Stichopus chloronatus and Linckia laevigata permanently occurred among macrophytes and corals.

Reef-flat community. Scleractinia Acropora cytherea or Porites lichen dominated both by the degree of substrate cover (20\% - 45\%) and by sizes of many-tier colonies reaching $3 \mathrm{~m}$ diameter. Montipora aequituberculata and Pachyseris rugosa were subdominants. Among the other corals Acropora humilis, A. robusta, Montipora digitata, Porites lobata, Goniastrea pectinata and Pavona decussate were the most frequently met. Echinoderms $H$. atra, $H$. edulis (density up to $4 \mathrm{spec} . \mathrm{m}^{2}$, biomass $\left.532.2 \mathrm{~g} / \mathrm{m}^{2}\right)$, Linckia laevigata, C. novaeguineae, mollusks Tridacna maxima, Cypraea tigris, C. arabica were permanent elements of the community. Small patches of the alga Caulerpa racemosa were met among coral colonies. Total substrate cover of corals was $60 \%$.

A community of soft corals Sinularia dura + Sarcophyton trochelioforum was formed at a depth of $4-15 \mathrm{~m}$ with the width of $20-80 \mathrm{~m}$. It was typical for open capes and inlets with rocky and large-lump substrate. Dominating alcyonarian $S$. dura occupied up to $40 \%-75 \%$ of substrate surface. Patches of combined colonies of the corals $A$. cytherea and $M$. aequituberculata with plate trochal colonies up to $3 \mathrm{~m}$ diameter were met in shallow parts of the community. Despite domination of soft corals in substrate cover, species diversity was ensured by scleractinian distributed in all part of the community. Acroporidae and branched Poritidae were the most frequent in its shallow part. Species of the genera Turbinaria, Porites, Goniopora, Galaxea, Hydnophora and Pachyseris, as well as Faviidae and Fungiidae, especially that of the genera Lithophyllum and Cycloseris, were distributed near the deep part of the reef slope.

Echinoderms Comatula pectinata, L. laevigata, $O$. nigra, Echinotrix calamaris, E. diadema, D. setosum, $H$. atra, $H$. edulis, and mollusks $O$. ovum and Lambis lambis were permanent components of all facies of the soft corals community. O. nigra (5 - 7 spec. $\left./ \mathrm{m}^{2}\right)$, C. pectinata $(10$ spec. $/ \mathrm{m}^{2}$ ) and $H$. edulis (4 spec. $\left./ \mathrm{m}^{2}\right)$ were the most frequent.

A community of Porites australiensis + Goniopora 
somaliensis with the width up to 40 - 60 m was observed from the upper reef slope up to pre-reef platform. It was typical for open inlets with stony and large-lump organogenic substrate. In the middle of the reef slope a facies of $M$. aequituberculata mono-colony could be formed, which ensured 100\% substrate cover together with Poritidae. Massive Porites colonies (up to $4.5 \mathrm{~m}$ in diameter) with growing on them scleractinian $A$. cytherea and $M$. aequituberculata were clearly distinguished in the same place. Other corals of the genera Pachyseris, Echinopora, Montipora, Porites, Micedium, Plesiastrea and Turbinaria occurred in a form of separate colonies or patches of colonies. Faviidae (up to 20 colonies per $\mathrm{m}^{2}$ ) with a diameter of 7 - $17 \mathrm{~cm}$ were chiefly developed.

On the whole, sufficiently homogenous distribution of corals and accompanying macrobenthos was typical for the reefs of the central Vietnam [2,12]. Zonal distribution of corals could be traced most clearly in open stony reef slopes, at shallow terraces and reef-flats of closed inlets in the presence of organogenic substrate of even small capacity. A similar situation was observed by Dai [13] in Taiwan and by Latypov [14,15] in North and South

\section{Vietnam.}

Development of mono-colonies of Acroporidae of the types $A$. cytherea and $M$. aequituberculata in reef-flat zones and on the upper reef slopes, and plate-foveolate colonies of the types Pachyseris, Mycedium, Echinophyllia on the lower slope part and on the pre-reef platform permitted us to integrate the studied reefs with the majority of Indo-Pacific and Atlantic reefs [16-20].

Investigation of reefs of $\mathrm{Ku}$ Lao Cham Islands, conducted by us in the last decade of May of 2010, made a distressing and painful impression. Practically nothing was left from the former richness and beauty of reefs of the reserved islands (Figure 2). Only 26 scleractinian species were revealed a result of three days of intensive hydrobiological survey conducted by hydrobiological experts, who spent underwater more than 48 hours and were equipped with modern photo techniques. The species diversity was reduced10-as a result of mortality of coral reefs along the entire coastline of these islands. There has been a reduction in the coverage of the substrate of Scleractinia and their replacement them by Alcyonarian (Table 1).

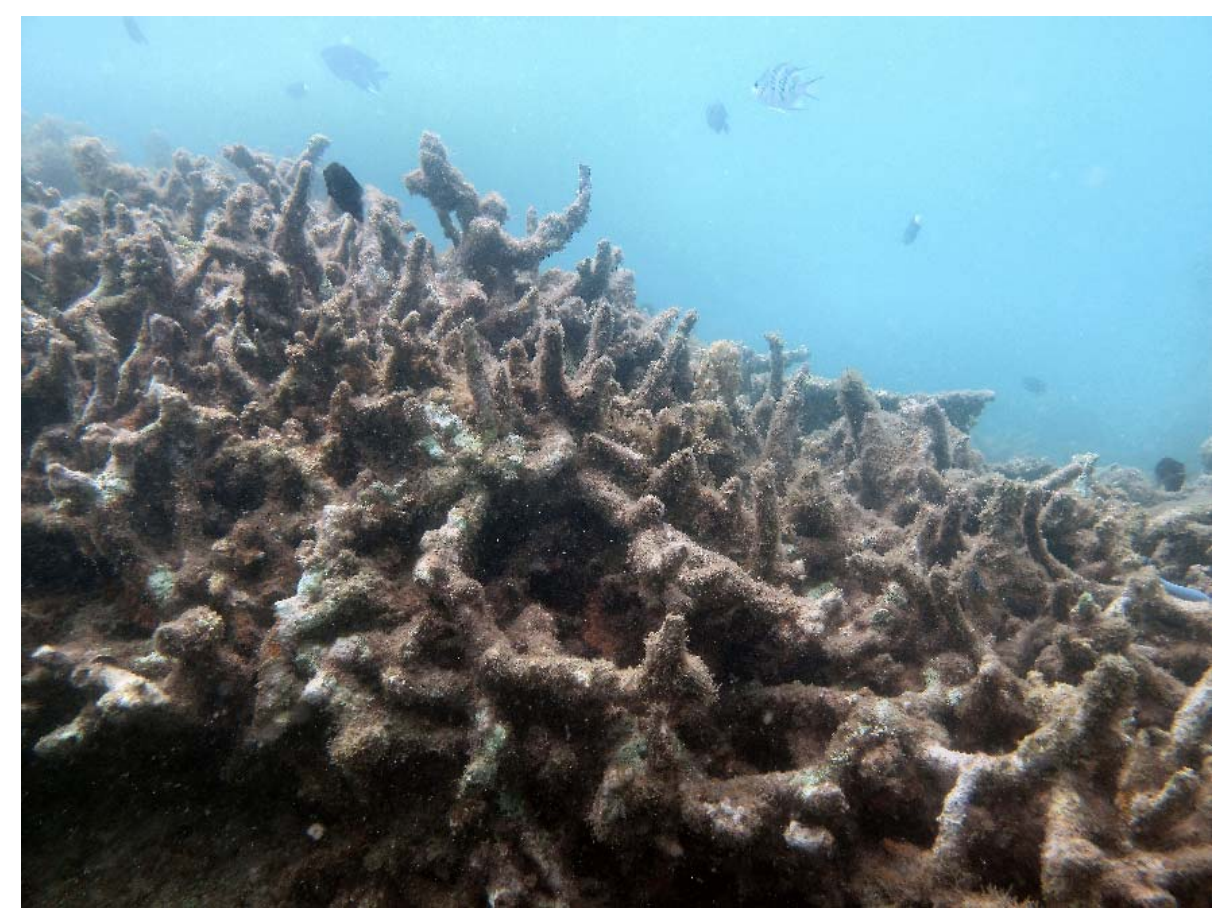

Figure 2. Physical destruction and covering Acropora mono-colony with sediments.

Table 1. Cover of hard corals and soft corals before and after the typhoon attack, \% covering of substratum.

\begin{tabular}{ccccccc}
\hline Subject & $\begin{array}{c}\text { Algal-coral } \\
\text { community }\end{array}$ & Inner reef-flat & Outher reef-flat & $\begin{array}{c}\text { Soft coral } \\
\text { community }\end{array}$ & $\begin{array}{c}\text { Porites }+ \text { Goniopora } \\
\text { community }\end{array}$ & Reef slope \\
\hline Macrophytes & $10-40 / 5-7$ & $7-10 / 10$ & $3-5 / 7-10$ & $3-5 / 10-12$ & $3-5 / 10-20$ & $1-5 / 5-7$ \\
Scleractinian & $10-15 / 0$ & $3-5 / 0.01$ & $45-60 / 0.1$ & $15-20 / 0.01$ & $100 / 0.0$ & $75-100 / 0.01$ \\
Alcyonarian & $3-7 / 10-18$ & $10 / 10$ & $15 / 45$ & $40-75 / 80-100$ & $0.0 / 100$ & $5-10 / 40-50$ \\
\hline
\end{tabular}


A heavy silting of substrate was the first thing noticed when diving. Even vagile animals were covered with a layer of sediments (Figure 3). At the same time, occurring almost everywhere alcyonarians and only single small scleractinian colonies, mostly also covered with silty sediments and various epibionts, were typical for the reefs [12,21-22]. Representatives of the Acroporidae family, which are mandatory members of all living reefs and usually form the bulk of their species diversity and a high degree of substrate cover by living corals, were completely absent at the reefs [23-25]. Reduction of species diversity of corals, degrees of substrate cover by corals, and growth delay with the increase of sedimentation have been mentioned in many publications [26-31]. Besides, intensive sedimentation can prevent coral larvae from settling and cause their high mortality after attachment to substrate due to mechanical abrasion. All that leads to fundamental changes in the scleractinian community and to a possible dominance of macrophytes and other coral competitors [32].

Single scleractinia, found here and there (2 - 4 colonies $/ \mathrm{m}^{2}$ ), are presented mainly by suppressed colonies of massive shape with maximum size of $10 \mathrm{~cm}$ in diameter. Massive Porites colonies (40\%) and representatives of Favia and Goniastrea (12\% each) were the most frequent. Blue corals Heliopora coerulea are distributed practically at all transects with a frequency of $7 \%-10 \%$. In situations like that it is possible to talk about absence of any degree of substrate cover by live corals or about its minimal size which as on the whole makes a small portion of $1 \%$. Colonies of massive Porites up to $1.5-2 \mathrm{~m}$ in diameter, which can ensure up to $25 \%$ - $40 \%$ degree of substrate cover on some areas of the transect, were found only near Tai Island (transect 4). Distribution of massive Porites is generally caused by the fact that these corals are able not only to survive in stressful environmental conditions but to reach dominance over the other scleractinian in productivity of organic material, degree of substrate cover and species diversity [14,27,33-35].

Occurring everywhere 10 - 15 species of alcyonarian soft corals play the main role in formation of communities on the present reefs of Ku Lao Cham Islands. Sarcophytum trochelioforum and Sinularia dura, which earlier also prevailed among alcyonarians both in occurrence frequency and in the ability to ensure $100 \%$ cover of the substrate, dominate [2]. So far inessential but ubiquitous settlement of algae Caulerpa racemosa, Padina australis, Halophyllia ovalis, Laurencia corymbosa and Asparagopsis taxiformis, which a quarter of a century ago were registered on living reefs only in the coastal zone, where they ensured up to $40 \%-60 \%$ of bottom cover on rocky substrate and dead corals, is now revealed on the reefs. As to macrobenthos, usually accompanying living coral communities and earlier forming mass as semblages, now single specimens of echinoderms $C$. pectinata, L. laevigata, O. nigra, D. setosum, $H$. atra and $H$. edulis, mollusks $L$. lambis, C. tigris, C. arabica and a number of other species-occur. It is necessary to mention

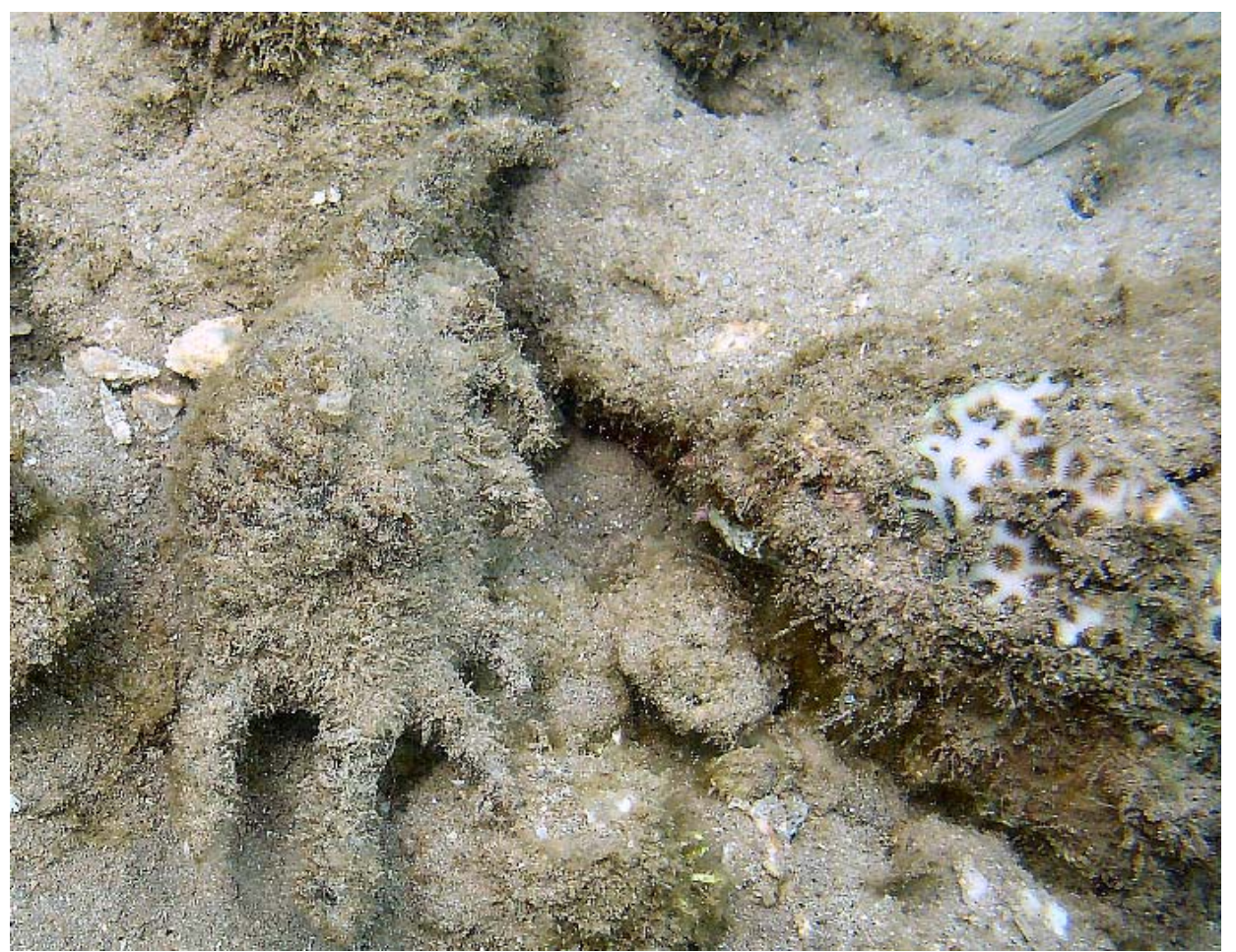

Figure 3. Substrate silting. Motile gastropod Lambis lambis at the left, a dead Faviidae colony at the recto. 
Sufficiently frequent occurrence of the predatory gastropod $O$. ovum (up to two specimens per one alcyonarian colony), for which soft corals serve as a main foodstuff. Distinct traces of Ovula attacks can be clearly seen on many alcyonarians colonies.

Morphological features and vegetative growth of soft corals permit them to endure easier stress situations, including mechanical damage by way of silting $[36,37]$. This adaptive strategy of alcyonarians permits them to form mono-dominant communities on many reefs of the Central Vietnam, which integrates them, on one hand, with reefs of Tonkin Bay and Taiwan with their special hydrodynamical conditions of increased sedimentation $[13,31,38]$, and, on the other hand, with reefs of the South Vietnam in the open part of the South China Sea $[15,39]$.

This adaptability of alcyonarians can be clearly observed on the studied degraded reefs. Replacement of the former scleractinian-alcyonarian community by a monodominant alcyonarian has occurred. Patches of alcyonarian settlements with the area up to several tens of square meters are distributed on all hydrobiological sections. At transects 2 and 3 they form compact settlements with $100 \%$ substrate cover for hundreds of square meters (Figure 4). Foraminifers, bryozoans, serpulids and drilling mollusks Litophaga spp. gain ground in the forming community together with scleractinian and macrophytes, which designates ecological type of succession of coelobytic and cryptic organisms [40]. Organisms with calcareous skeletons, especially crustacean calcareous algae, play the main role at the initial succession stages in formation of a stable substrate for settling and growth of hermatypic corals [41]. In 2 - 3 years after calcareous substrate formation the dominance of reef building coral colonies become appreciable, and only in 4 - 6 years after the beginning of a new reef colonization appearance of vast colonies of Acropora corals is possible [40,42].

However, a hope for restoration of the studied reefs is available, as we nevertheless managed to find single, very small, young, settled a new colonies of Pocillopora verrucosa-one scleractinian species on all Indo-Pacific reefs.

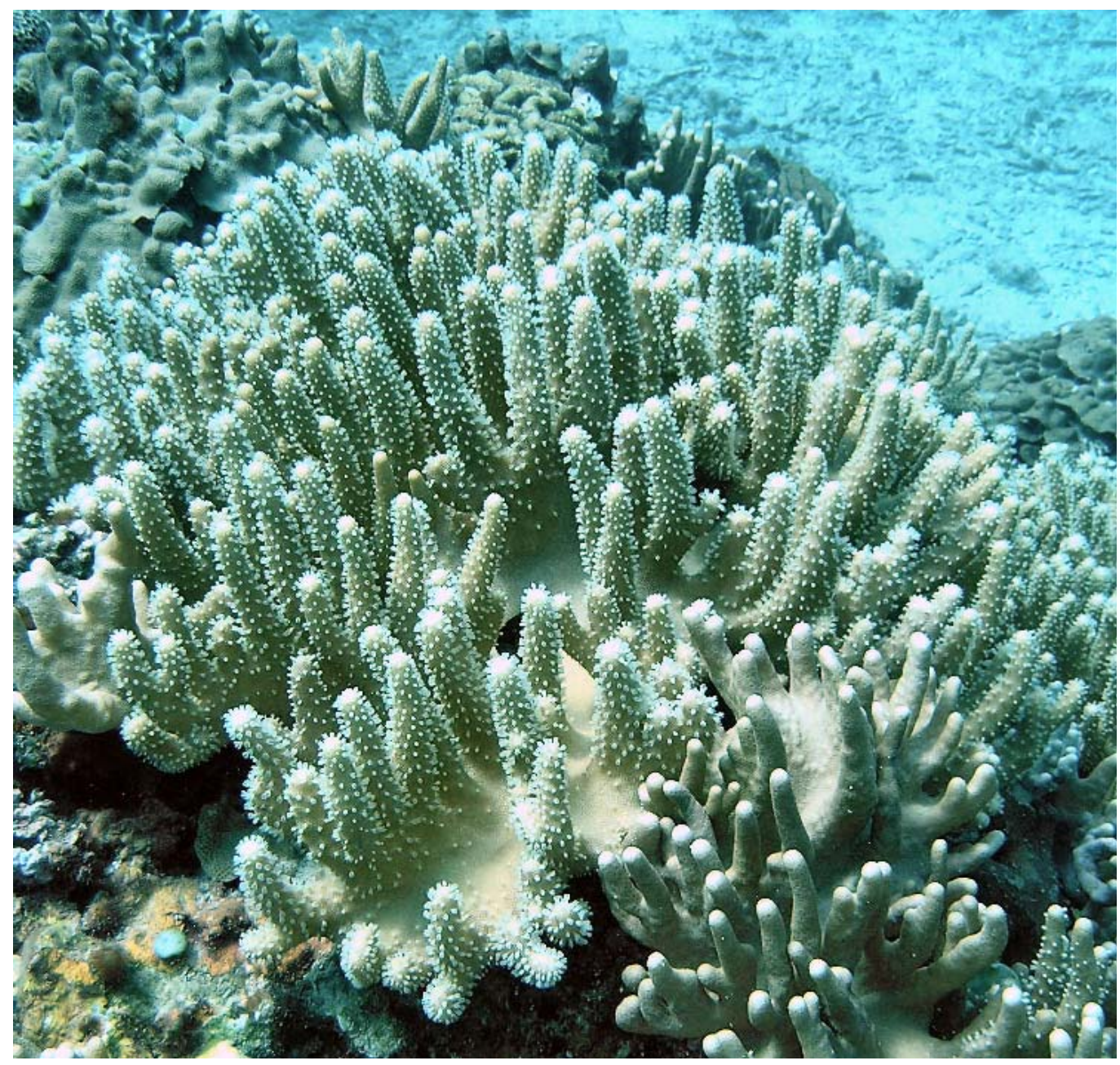

Figure 4. A mono-colony of the alcyonarian Sarcophytum trocheliophorum. 


\section{Acknowledgements}

We are grateful to E. Kogan for translation of article into the English. Special thanks to Prof. James Crabbe for his valuable and constructive remarks to the manuscript of the article.

\section{REFERENCES}

[1] T. D. Thanh, "Change in Environment and Ecosystems Relative to the Land-Sea Interaction in the Vietnam Coastal Zone,” Reports EALOICZ Workshop, Qingdao, 1999, pp. 1-10.

[2] Yu. Ya. Latypov, "Communities of Coral Reefs of Central Vietnam,” Russian Journal of Marine Biology, Vol. 27, No. 4, 2001, pp. 197-200. doi:10.1023/A:1011939501255

[3] "WWF Vietnam Marine Conservation Southern Survey Team Survey Report on the Biodiversity, Resource Utilization and Conservation Potential of Cau Islands, Binh Thuan Province, S. Vietnam. Inst. Oceanog. (Nhatrang, Vietnam \& WWF International Gland, Switzerland)," Unpublished Report, 1993.

[4] D. Yellowleess, "Land Use Patterns and Nutrient Loading of the Great Barrier Reef Region: Proceedings of the Workshop Held at the James Cook University of North Queensland," Sir George Fisher Centre for Tropical Marines Studies and James Cook University of North Queensland, Queensland, 1991.

[5] P. R. F. Bell, "Eutrophication and Coral Reefs-Some Examples in the Great Barrier Reef Lagoon," Water Research, Vol. 26, No. 5, 1992, pp. 553-568. doi:10.1016/0043-1354(92)90228-V

[6] C. G. J. Petersen, "The Animal Association of the Sea Bottom in the North Atlantic," Kobenhavn Berlin Biology Stantion, 1914, Vol. 22, pp. 89-98.

[7] Y. Loya and L. B. Slobodkin, "The Coral Reefs of Elate (Gulf of Elate. Red Sea),” Journal of Sampling ZoologySocieaty London, Vol. 28, 1971, pp. 117-140.

[8] J. E. N. Veron and M. G. S. Smith, "Coral ID: An Electronic Key to the Zooxanthellate Scleractinian Corals of the World,” Australian Institute of Marine Science, Townswill, 2004.

[9] Yu. Ya. Latypov, "The Common Coral of Vietnam: Field Handbook,” Far Eastern National University Press, Vladivostok, 2006.

[10] S. Weinberg, "A Comparison of Coral Reef Survey Methods," Bijdragen Tot De Dierkunde, Vol. 51, No. 2, 1981, pp. 199-218.

[11] W. Leujak and R. F. G. Ormond, "Comparative Accuracy and Efficiency of Six Coral Community Survey Methods," Journal of Experimental Marine Biology Ecology, Vol. 351, No. 1-2, 2007, pp. 168-187. doi:10.1016/j.jembe.2007.06.028

[12] Yu. Ya. Latypov, "Reef-Building Corals of Vietnam as a Part of the Indo-Pacific Reef Ecosystem,” Russian Journal of Marine Biology, Vol. 31, 2005, pp. S34-S40. doi:10.1007/s11179-006-0013-5
[13] C.-F. Dai, "Patterns of Coral Distribution and Benthic Space Partitioning on the Fringing Reefs of Southern Taiwan,” Marine Ecology, Vol. 14, No. 3, 1993, pp. 185203. doi:10.1111/j.1439-0485.1993.tb00479.x

[14] Yu. Ya. Latypov, "Coral Communities of the Namsu Islands (Gulf of Siam, South China Sea),” Marine Ecology-Progress Series, Vol. 29, 1986, pp. 261-270. doi:10.3354/meps029261

[15] Yu. Ya. Latypov, "Benthic Communities of Coral Reefs of Tho Chu Island (Gulf of Siam, South China Sea)," Biology Morya, Vol. 25, No. 3, 1999, pp. 233-241.

[16] D. R. Stoddart, "Post-Hurricane Changes on the British Honduras Reefs and Cays: Re-Survey of 1965," Atoll Research Bulletin, Vol. 25, No. 131, 1969, pp. 259-268.

[17] C. R. C. Sheppard, "Coral Population on Reef Slopes and Their Major Controls,” Marine Ecology-Progress Series, Vol. 7, 1982, pp. 83-115. doi:10.3354/meps007083

[18] D. H. H. Külmann, "Composition and Ecology of DeepWater Coral Associations," Helgoland Marine Research, Vol. 36, No. 2, 1983, pp. 183-204. doi:10.1007/BF01983856

[19] C.-F. Dai, "Interspecific Competition in Taiwanese Corals with Special Reference to Interactions between Alcyonaceans and Scleractinians," Marine Ecology-Progress Series, Vol. 60, 1990, pp. 291-297. doi:10.3354/meps060291

[20] Yu. Ya. Latypov, "Community Structure of Scleractinian Reefs in the Baitylong Archipelago (South China Sea)," Asian Marine Biology, Vol. 12, 1995, pp. 27-37.

[21] Yu. Ya. Latipov, “Scleractinian Corals of Vietnam,” The Soviet Journal of Marine Biology, Vol. 13, 1987, pp. 246252.

[22] M. B. Best, B. W. Hoeksema, W. Moka, H. Moli and I. N. Sutarna, "Recent Scleractinian Corals Species Collected during the Snellius-II Expedition in Eastern Indonesia," Netherlands Journal of Sea Research, Vol. 23, No. 2, 1989, pp. 7-115. doi:10.1016/0077-7579(89)90005-7

[23] J. E. N. Veron and G. Hodgson, “Annotated Checklist of the Hermatypic Corals of the Philippines," Pacific Science, Vol. 43, No. 3, 1989, pp. 234-287.

[24] J. E. N. Veron, "Corals in Space and Time: The Biogeography and Evolution of the Scleractinia," Cornell University Press, New York, 1995.

[25] S. Vo and G. Hodgson, "Coral Reefs of Vietnam: Recruitment Limitation and Physical Forcing,” Proceeding of the 8th Internet Coral Reef Symposium, Vol. 1, 1997, pp. 477-482.

[26] J. Cortés and M. J. Risk, “A Reef under Siltation Stress: Cahuita, Costa Rica,” Bulletin Marine of Science, Vol. 36, No. 2, 1985, pp. 339-356.

[27] T. Tomascik and F. Sander, "Effects of Eutrophication on Reef Corals,” Marine Biology, Vol. 94, No. 1, 1987, pp. 53-75. doi:10.1007/BF00392900

[28] K. Sakai and M. Nishihira, "Immediate Effect of Terrestrial Runoff on a Coral Community near a River Mouth in Okinawa,” Galaxea, Vol. 10, 1991, pp. 125-134.

[29] K. P. Sebens, "Biodiversity of Coral Reefs: What Are We Losing and Why?” American Zoologist, Vol. 34, 1994, pp. 
115-133.

[30] N. G. Andres and J. D. Witman, "Trends in Community Structure on a Jamaican Reef," Marine Ecology-Progress Series, Vol. 118, 1985, pp. 305-310. doi:10.3354/meps118305

[31] Yu. Ya. Latypov, "Macrobenthos Communities on Reefs of the An Thoi Archipelago of the South China Sea," Russian Journal of Marine Biology, Vol. 26, No. 1, 2000, pp. 18-26. doi: 10.1007/BF02759489

[32] B. Salvat "Dredging in Coral Reefs," In: B. Salvat, Ed., Human Impact on Coral Reefs: Facts and Recommendations, Museum National D’histoire Naturelle et École Pratique des Hautes études, Antenne de Tahiti \& Centre de l'Environnement, California, 1987, pp. 165-184.

[33] K. Sakai, T. Yeemin, A. Svidvong and M. Nishihira, "Distribution and Community Structure of Hermatypic Corals in the Sichang Islands, Inner Part of the Gulf of Thailand,” Galaxea, Vol. 5, No. 1, 1986, pp. 27-74.

[34] D. C. Miller, M. J. Bock and E. J. Turner, "Deposit and Suspension Feeding in Oscillatory Flows and Sediment Fluxes,” Journal of Marine Research, Vol. 50, No. 3, 1992, pp. 489-520. doi:10.1357/002224092784797601

[35] M. M. Mills and K. P. Sebens, "Ingestion and Assimilation of Nitrogen from Benthic Sediments by Three Species of Coral,” Marine Biology, Vol. 145, No. 6, 2004, pp. 1097-1106. doi:10.1007/s00227-004-1398-3

[36] M. A. R. Koehl, "Mechanical Design of Spicule-Rein- foreed Connective Tissues: Stiffness,” Journal of Experimental Biology, Vol. 98, 1982, pp. 239-267.

[37] C.-F. Dai, "Distribution and Adaptive Strategies of Alcyonacean Corals in Nanwan Bay," Hydrobiologia, Vol. 216, No. 1, 1991, pp. 241-246. doi:10.1007/BF00026469

[38] Yu. Ya. Lalypov and A. N. Malyutin, "Structure of Coral Communities on the Eastern Part of Baitylong Archipelago, South China Sea,” Asian Marine Biology, Vol. 13, 1996, pp. 15-24.

[39] Yu. Ya. Latypov, "Benthic Communities of the Coral Reefs of the Kondao Islands in South China Sea," Russian Journal of Marine Biology, Vol. 19, No. 5-6, 1993, pp. 310- 318.

[40] D. R. Choi, "Ecological Succession of Reef Cavity- Dwellers (Coelobites) in Coral Rubble," Bulletin Marine of Science, Vol. 35, No. 1, 1984, pp. 72-79.

[41] H. Ohba, K. Hashimoto, K. Shimoike, T. Shibuno and Y. Fujioka, "Secondary Succession of Coral Reef Communities at Urasoko Bay, Ishigaki Island, the Ryukyus (Southern Japan)," Proceeding of the 11th Internet Coral Reef Symposium Ft Lauderdale, Florida, 7-11 July 2008, pp. 319-327.

[42] B. V. Preobrazhensky and Yu. Ya. Latypov, "Regeneration Processes in the Coral Reef Ecosystem," Biology, Morphology, Taxonomy and Ecology of Coral Reefs, Moscow, 1980, pp. 5-12. 